\title{
The Spirit of the Cloud: The 'New Jerusalem' as a metaphor for social experiences of virtual technologies
}

\author{
Moshe Caine \\ Hadassah Academic College \\ Jerusalem, Israel \\ mosheca@hac.ac.il \\ Eytan Mann \\ Scan the City \\ Tel Aviv, Israel \\ eytan@scanthecityproject.com
}

\author{
Doron Altaratz \\ Hadassah Academic College \\ Jerusalem, Israel \\ doronal@hac.ac.il \\ Adam Havkin \\ Scan the City \\ Tel Aviv, Israel \\ adam@scanthecityproject.com
}

\begin{abstract}
Over the past centuries, the city of Jerusalem has been a centre for social and spiritual experiences of diverse communities separated from their homes and cultures. The crusaders notion of a 'New Jerusalem'; the physical reconstruction of the holy city of Jerusalem in Europe has been reversed and implemented through remote communities who moved to Jerusalem from overseas and reconstructed their home and places of worship. This project aims to express and enhance the dialectical relationship between diverse geographical locations, manifested through lost and reborn communities, the old and the New Jerusalem. Two very different, yet historically linked test cases are explored: The reconstructed Synagogue of the lost community of Conegliano Veneto, Italy, and the Kidane Mehret Ethiopian Church. Both located today in Jerusalem. Through the use of advanced photogrammetry, we attempt to create an emotional experience, transcending time and space and intensifying the complex experience of life in a home away from home. The two structures are recreated as 3D point clouds, enhanced by sounds of prayer and blended with historical imagery. The relationship between technology and meaning can be seen as an extension of the age-old mind-body problem. That is, how the physical and technological process may influence emotion and the subjective experience. The 'Spirit of the Cloud' attempts to bridge this gap by offering a personal encounter, which transcends the objectivity of technology and elevates the subject into a personal spiritual voyage. This is attempted by providing an immersive multisensory experience, combining eye, ear and physical interaction. Two integral components contribute towards this: The virtual reality headset and the point cloud audio-visual experience, These aim to create a spiritual voyage, where one may wander at will and experience the atmosphere of a twilight zone, bound neither by space nor time, yet strongly attached to both. The paper outlines the considerations, limitations, and solutions undertaken in the digital recreation of the structures. Likewise, it explores the process of fusing the technical challenge with the desired emotional impact on the user.
\end{abstract}

Jerusalem. Church. Synagogue. Point cloud. Photogrammetry. Virtual reality.

\section{INTRODUCTION}

In the year 1888, Jerusalem, the ancient holy city, which for thousands of years lay cramped within its protective walls, has grown in numbers. The latest walls, dating to the 16th century Ottoman Empire can no longer contain its population. In the late 1850s, Sir Moses Montefiore, a son-in-law of the Rothschilds, visits the city. Troubled by the plight of his fellow Jews he purchases a plot of land on an open hillside, west of the city, outside the walls. This signals the start of an exodus from the old city and the beginnings of the 'New Jerusalem' (Isaacs 2005).

Christian Europe rediscovered Jerusalem in the 19th century. The budding sciences of archaeology, geography, photography and anthropology made major inroads in Jerusalem at this time. 19th century explorations of Jerusalem produced a wealth of information and literature, which did much to arouse western interest in the city. The explorers came motivated by religion, intellectual curiosity and romantic imagination. 


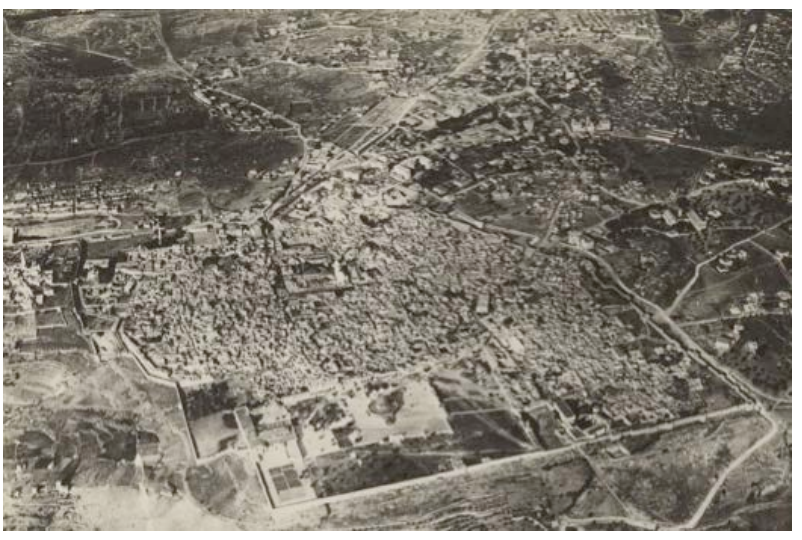

Figure 1. Jerusalem 1917.

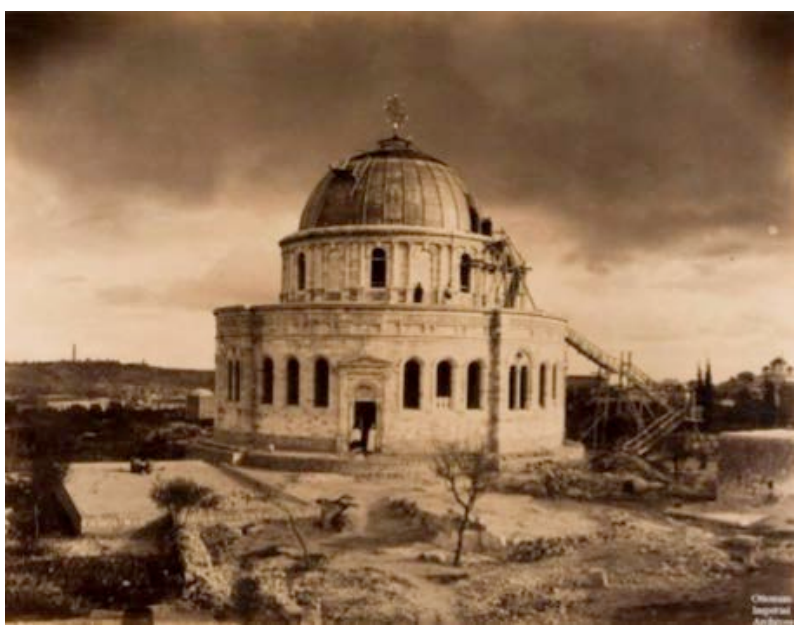

Figure 2: Construction of the Ethiopian Church. From the Ottoman Imperial Archive (date unknown).

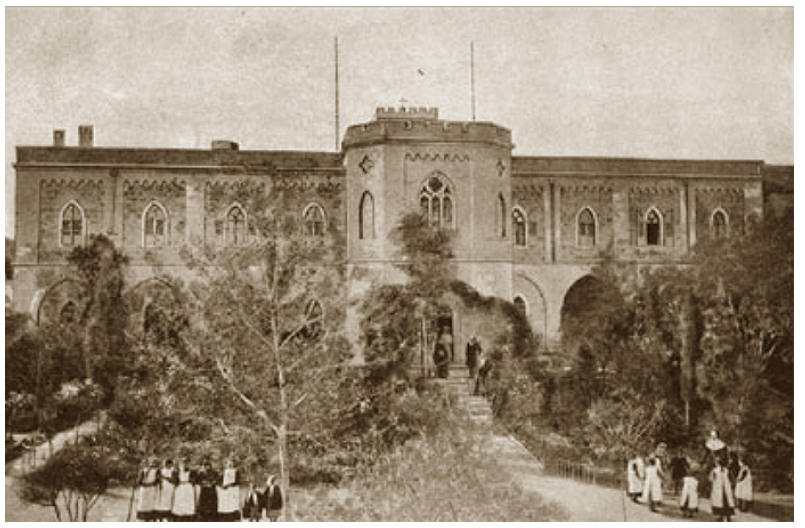

Figure 3: Schmidt building. Lande Ein alter schlesischer Pionier, Nicolai O. S. Druck von C. Miarka, G. m. b. H., 1911.

Alongside this came a sharp upsurge of Christian religious activity in Jerusalem. The Latin Patriarch resumed residence in Jerusalem, as did the Greek Orthodox Patriarch. The Anglicans engaged in missionary activity aimed at converting Jews to Christianity. In order to advance this goal, they established schools and a hospital. This period also witnessed the development of the Ethiopian
Orthodox community in Jerusalem. From the second half of the nineteenth century, Ethiopians could acquire houses and lands in Jerusalem. In 1888, not 300 meters away, The Ethiopian Emperor Yohanes bought a plot of land and began construction of a new church and monastery for his growing community. The complex eventually lent its name to the road on which it is situated - Ethiopia Street. (Ben-Nathan 2012) In the year 1905, the Ottoman authorities designated a part of the town as Haret al-Habash, known today as the Ethiopian Compound.

Meanwhile, just a stone's throw away, another religious complex had just been completed. The Schmidt building in the heart of Jerusalem. Built originally as a German Catholic Institution, it was also called the German Compound and named after Wilhelm Schmidt (1833-1908), a Lazarist priest who headed the German Catholic Society in Palestine for many years. The building served both as a hospice for pilgrims and as a centre for philanthropic activity.

Yet, as so often in Jerusalem, religious practice, history, politics and location intertwine. Thousands of miles from Jerusalem, in the small town of Conegliano Veneto, Italy, a religious transition was also taking place. Jews had lived in Conegliano from the sixteenth century and prayed in a small synagogue. As the community dwindled the synagogue remained in sporadic use until the First World War. The last service was held on The Day of Atonement in 1919 by Jewish soldiers of the Austro-Hungarian army.

In 1944, when the last member of the Jewish community, Adolfo Vital, died, the community ceased to exist. Nevertheless, spiritual buildings can sometimes transcend the demise of their community. Thus, in 1951 following the establishment of the state of Israel, the synagogue was transferred in its entirety to Jerusalem, where the original hall was reconstructed in all its detail, in no other than the Schmidt building. Today the synagogue is in constant use by the Italia community of Jerusalem, descendants of Rome, Florence, Torino, mantua and other communities (Contessa 2014).

\section{TEST CASES}

\subsection{The Kidane Mehret Ethiopian Church}

There are two forms of native Ethiopian churches: one oblong, traditionally found in Tigray, the other circular, as traditionally found in Amhara and Shewa. The Kidane Mehret Church in Jerusalem follows this style, round in shape with a dome of some 30 meters in height. 


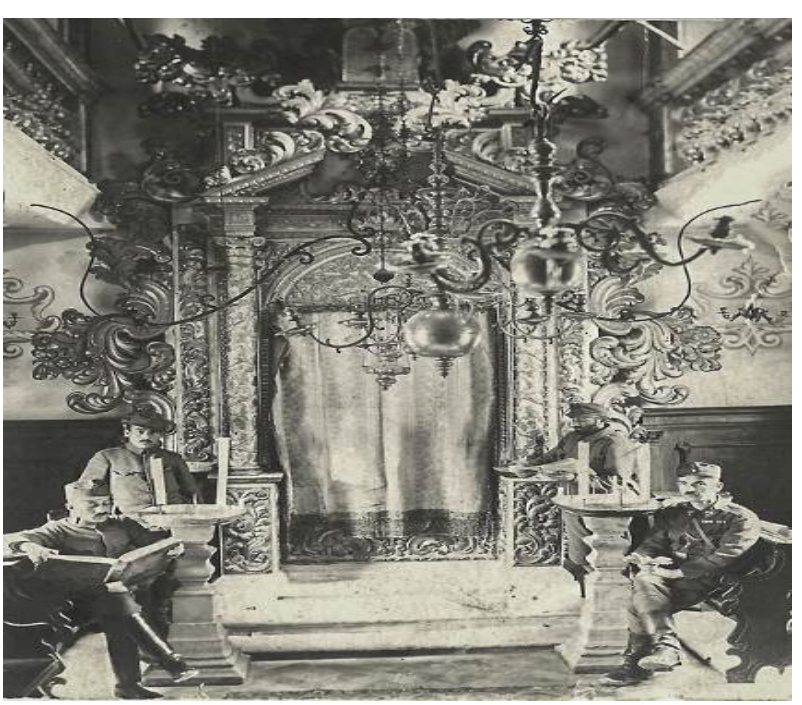

Figure 4: Soldiers of the Austro-Hungarian Army at the Synagogue. Yom Kippur 1919. Nahon Museum archives.

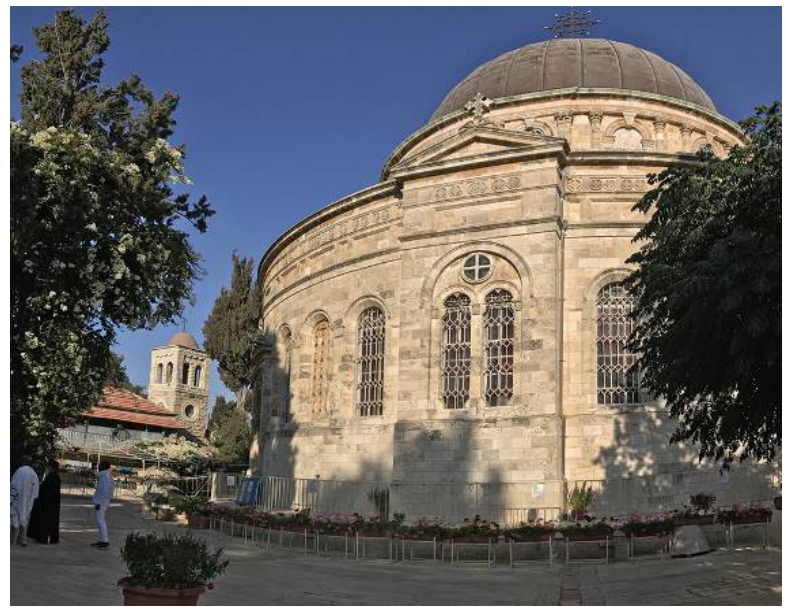

Figure 5: The Ethiopian Church. Photo: M. Caine.

The interior consists of three concentric rings. In

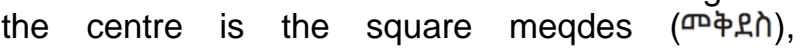
'sanctuary' (Mikdash in Hebrew), also called the qiddiste qiddusan ( $\$$ s? (Kodesh Hakodashim in Hebrew), which only priests and deacons may enter and which contains the tabot, the tablet over which the Eucharist is celebrated. Around this is the circular part known

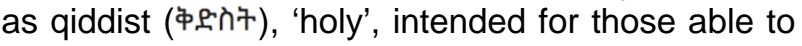
receive Holy Communion. The outer circular ring, the qne mahlet (蛒叫衲年) is for the cantors and is accessible to public prayer (Twite 1996).

\subsection{The Conegliano Veneto Synagogue}

16th century Italian Synagogues were built in the Jewish Ghettos by Christian craftsmen, as this work was not permitted to Jews. Architecturally they were therefore a meeting between two opposite trends. One, which copied the artistic abilities of the Church, and the other, which veered away from it. Nevertheless, the sensitivity to art in
Italy was so great that even the veil of the Ghetto could not block it and the Jews both absorbed it and were highly influenced by it, especially in the field of Synagogue decoration. The elegance of the interiors stood in stark contrast to the humble exteriors, which, both in line with the severe conditions imposed by the authorities and the security considerations self-imposed by the community, prevented any expressions of artistic and architectural luxury (Cassuto 2012).

\section{PROJECT RATIONALE}

As we have seen, the expanses of time and space are relative. Distances are measured sometimes less by actual miles than by human desires and yearnings, and the span of time counted less by calendar years than by memories and dreams. The magnetic and mystical pull of Jerusalem has for millennia drawn the faithful and the fanatics alike from the four corners of the earth.

Yet, as the saying goes: You can take an Englishman out of England, but you can't take England out of the Englishman. Thus, even as the ongoing waves of immigration established their new centres of worship in the holy city of Jerusalem, they still maintained an unbroken link to their past and their homeland, be it Italy, Germany, Greece, Russia, or Ethiopia. This project aims to express and enhance the dialectical relationship between present and past, lost and reborn communities, the old and the New Jerusalem.

\subsection{The virtual pilgrim}

The concept of Simulacrum and the New Jerusalem gives rise to the fundamental question: Can the VR voyage act as a virtual substitute for the pilgrimage journey? Central to this is the even deeper question: does a spiritual pilgrimage necessarily involve a physical journey? Is it possible that 'arriving' does not involve going out at all, but is rather an introspective process?

This dilemma is not new. As early as 1480, following his pilgrimages to the Holy Land, the Dominican theologian Felix Fabri wrote instructions to his followers on how to experience a spiritual pilgrimage. (Fabri 1848) In recent years, with the dominance of the digital world and the Internet, the issue has become more prominent. A multitude of websites offer virtual experiences in lieu of physical travel (e.g. http://jerusalemexperience.com and http://www.jesus2000.com). Lately, the escalation of the worldwide Coronavirus has heightened the potential dangers of travel. Does the VR pilgrimage offer a viable alternative? 


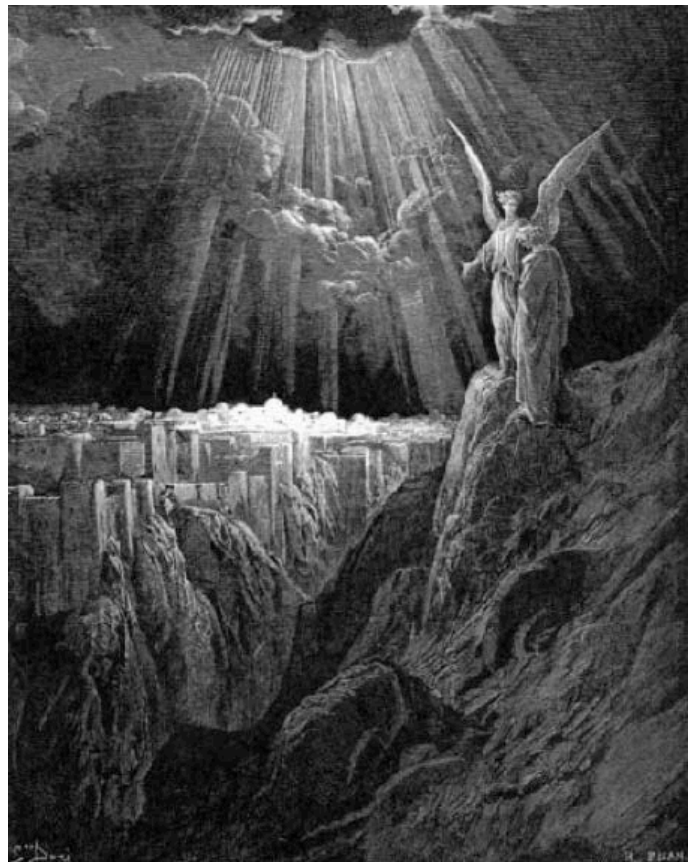

Figure 6: Revelation. Gustave Dore (1832-1883).

\subsection{Utopia, simulacrum and the New Jerusalem}

The utopian idea behind the manifestation of the New Jerusalem' is deeply rooted in the ritual of pilgrimage, where pilgrims, returning to their homes in Europe, brought with them artefacts of the holy land as souvenirs.

Later when the physical link to the holy land was lost, churches representing the holy places were built throughout Europe, acting as a spiritual substitute to the old city of Jerusalem. These locations are described an ideal rather than real places. A utopia. A better Jerusalem. A copied image of a utopian idea disconnected from its original concept and evolving into a truth of its own. The term 'Utopia' means 'no place' in Greek and is associated with Thomas More (b.1478). More coined the word in his famous book of that name, to describe an island community with an ideal mode of government. First published in Latin in 1517 , this concept of an ideal world and society resonates throughout history, in religions and within secular belief systems.

Churches in general, and the Church of England in particular, have long used Jerusalem as a metaphor for Heaven, a place of universal love and peace.

And I saw a new heaven and a new earth; for the former heaven and the former earth were passed away; and the sea was no more. And I, John, saw the holy city, the New Jerusalem, descending from God out of heaven, prepared like a bride adorned for her husband... (Revelation 21: 1-2)
In his famous poem dated 1808 'Jerusalem' the English Romantic William Blake (1757-1827) describes the 'dark satanic mills' where men and women toiled to create enormous wealth for a few.

I will not cease from Mental Fight,

Nor shall my Sword sleep in my hand:

Till we have built Jerusalem,

In England's green \& pleasant Land.

One of the most beautiful expressions of this concept of an imaginary city, born of dreams, desires and memory, appears in the book 'Invisible Cities' by Italo Calvino in 1972.

Calvino's 'Invisible Cities' consists of a sequence of imaginary dialogues between the Venetian traveller Marco Polo and the Tartar emperor Kublai Khan. In these discussions, Polo describes a series of imaginary cities including among others, Cities and Desires, Cities and Memory, Cities and the Sky, and Hidden Cities.

This belief is handed down in Beersheba: that, suspended in the heavens, there exists another Beersheba, where the city's most elevated virtues and sentiments are poised, and that if the terrestrial Beersheba will take the celestial one as its model the two cities will become one (Cities and the Sky).

\section{THE EXPERIENCE}

It is this sense of dynamic dialectic tension between dream and reality, between mystique and objectivity, the here and now and the imaginary, that this project attempts to express and explore.

By allowing the viewer to immerse in a virtual reality experience, equipped with VR goggles (such as the Oculus Rift), we wish to enable the user to navigate at will through the point cloud structures of both the Ethiopian Church and The Conegliano Italian Synagogue. Enhanced by the traditional sounds, chants, hymns and prayers, as well possibly as with historical photographic materials, we aim to create an emotional experience, transcending time and space and intensifying the complex experience of life in a home away from home; a 'virtual pilgrimage'.

In this respect, contemporary virtual reality could be considered as the New Jerusalem of socialtechnology, a redefined form of simulacrum, where the user (the believer) experiences a 'virtual pilgrimage' as 'a potential pilgrim which is 'out there' without ever stepping foot on an actual pilgrim road'. 


\section{APPLICATION OF TECHNOLOGY}

Technology is just a tool. It is man that gives it meaning.

The relationship between technology and meaning can be seen as an extension of the age-old mindbody problem. That is, how the physical and technological process may influence emotion and the subjective experience. The 'Spirit of the Cloud' project attempts to bridge this gap by offering a personal encounter, which transcends the objectivity of technology and elevates the subject into a personal spiritual voyage. This is attempted by providing a multi-sensory experience, combining eye, ear and physical interaction. Two integral components contribute towards this: The virtual reality headset and the Point Cloud visual experience.

\subsection{The virtual reality headset}

Central to the experience of the VR headset is the disconnection of the user from his immediate surroundings. The visual and auditory sensory inputs are cut off and replaced by those fed into the user by the headset. This effectively captivates the user and cuts him off from his 'here and now' faculties. The immersive experience is directly fed into his eyes and ears, effectively taking over control.

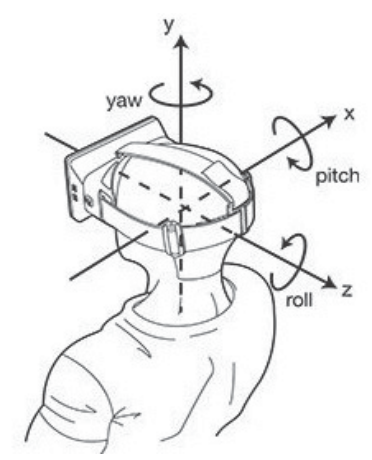

Figure 7: The Oculus Rift environment.

VR headsets are not uniform in their function. Essentially, two types exist: The simpler ones are those that place the user in a fixed point in 3D space, offering a $360 \times 180$ degree view. The more advanced, such as the Oculus Rift allow the user to move freely and at will within the virtual space, as music and sounds engulf the user and the world around him is transformed into an array of coloured dots, the point cloud.

\subsection{The point cloud and photogrammetry}

The point cloud is a digital representation of threedimensional space. In photogrammetry, 3D laser scanning and other optical acquisition technologies it is the primary source of the three-dimensional digital structure.

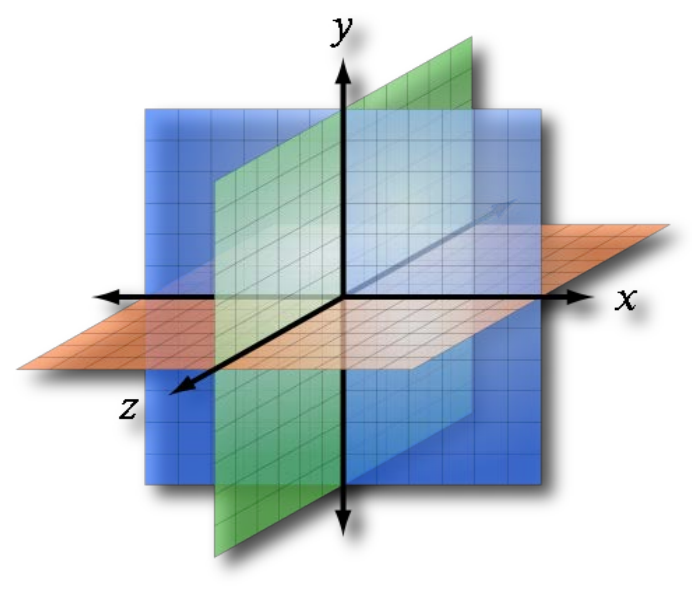

Figure 8: 3D Space.

Photogrammetry is the extraction of threedimensional measurements from two-dimensional data. In practice this means the extraction of the full $X Y Z$ coordinates of the point cloud by means of multiple photographs. Each (control) point on the $3 d$ surface needs to be photographed from at least two different angles. Using the basic principles of triangulation, it is then possible to determine the distance of the object from the camera, i.e. the $Z$ coordinate. In this respect it can be regarded as equivalent or akin to a 3D photographic pixel. It signifies a mathematical point in 3D space, devoid of actual size, but like the two-dimensional pixel it is represented in a given dimension relative to the display mechanism choice. In the same way that the digital photograph is comprised of many hundreds or thousands of pixels, each containing parameters of colour and intensity, so too the point cloud is a dense clustering of a vast number of points in space, each representing the RGB value and intensity of light reflecting off a single point.

In conventional 3D modelling, these points are then connected to create a mesh, and the mesh is further surfaced with a texture, either derived from the photographic data or created artificially by software. Thus, the 3D model surface is solid and opaque, mimicking the original structure. The point cloud, on the contrary is not solid. Like a cluster of locusts in the sky, dots on the printed page or pixels on a screen, the cloud is measured by its density, i.e. by the distance between the dots. The denser the dots, the more seemingly opaque the scene. The sparser the dots, the more transparent.

Likewise, the apparent density of the cloud will be relative to the distance from which it is viewed. As we approach the cloud, the apparent distance between the dots will grow, and vice versa as it 
recedes into the distance. Because a point cloud is entirely mathematical and based on principles of trigonometry, we may place our viewpoint (camera) at any point in space. Furthermore, we may change our viewpoint at will and 'travel' through the clouds like a bird or a plane. As we approach the pixels, they grow larger and further apart. Unlike a standard 3D structure, the walls are never fully solid. Ceilings and floors no longer constrain our path of flight and space assumes a dreamlike quality.

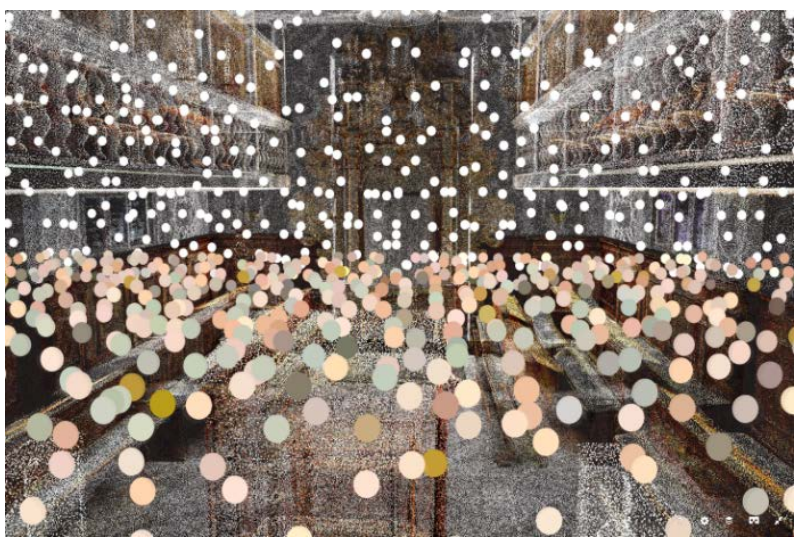

Figure 9: traveling through the Point Cloud of the Conegliano Synagogue.

\subsection{Technological challenge}

VR experiences are not new. Computer games abound and are highly immersive. However, usually they are based on rapidly processed lowpolygon models enhanced by photorealistic textures to enhance the visual experience. 'The Spirit of the Cloud' experience is however based and dependent on a high-resolution point cloud. This places a hefty load on the computer processors, especially when displayed in the context of an interactive experience running at 30 FPS. Currently, various optimisation approaches are being tested in both the Unity and the Unreal Engine software in an attempt to reach an acceptable balance for a good user experience.

\subsection{Creating the point cloud}

The practicalities of imaging the two structures were challenging to say the least. Some of the obstacles were technical, but no less were the religious, bureaucratic/political ones. The two went hand in hand.

The Ethiopia church is 30 meters high. All requests for permission to enter with a laser scanner, or even a tripod, were turned down. Likewise, there was no possibility whatsoever to use a ladder, let alone a drone. The interior was extremely dark and could not be lit, so all photography had to be performed with available light. For these reasons, following tests with a DSLR and even a 360 camera, the unusual choice was made to shoot with an iPhone 11, which offered very good low light quality. Ultimately, the photogrammetric model was constructed with some 2500 images, taken discreetly over some 5 separate visits.

The Italian Synagogue on the other hand proved a friendlier experience. After several initial tests of photogrammetry, we were fortunate to gain access to a Faro Focus S150 Laser scanner. Some 50 scans were needed to cover the Synagogue interior.

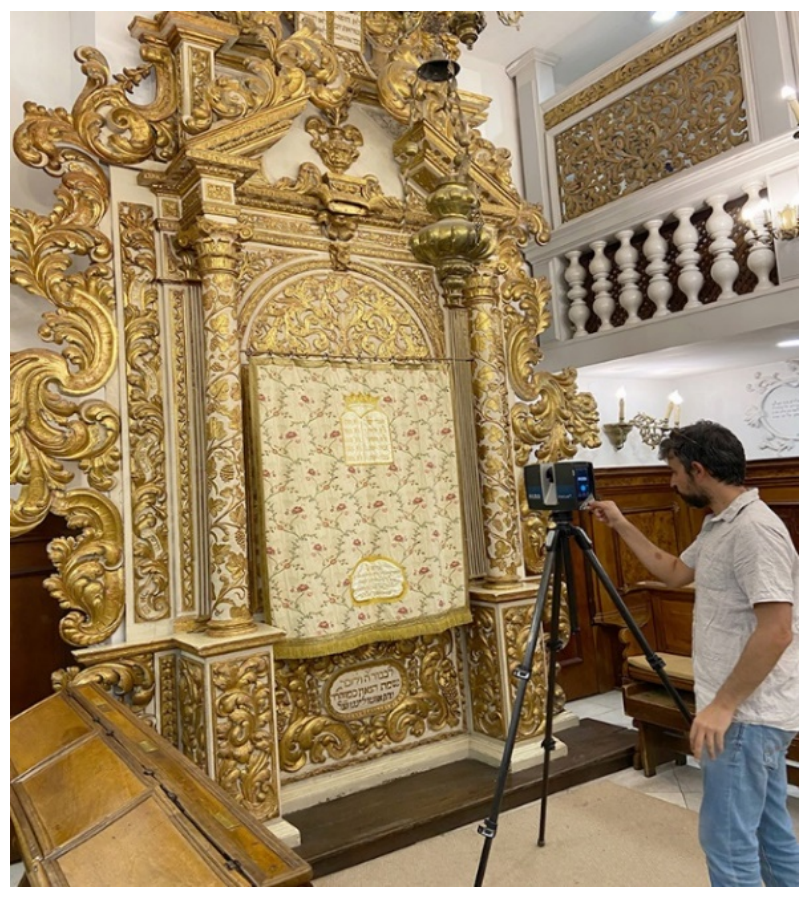

Figure 10: Laser scanning the Synagogue Ark.

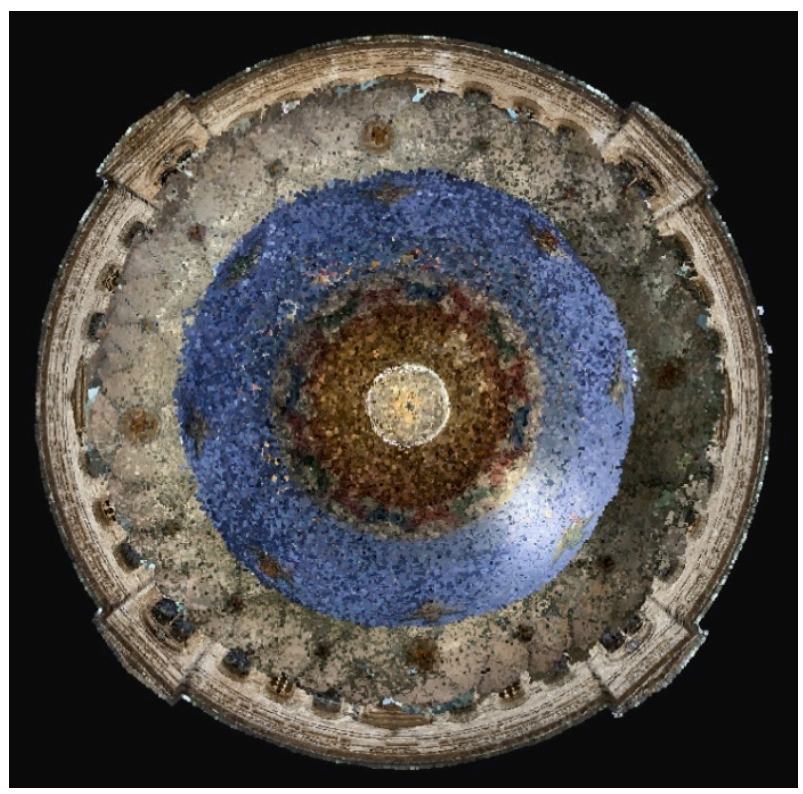

Figure 11: Top view point cloud of the church. 


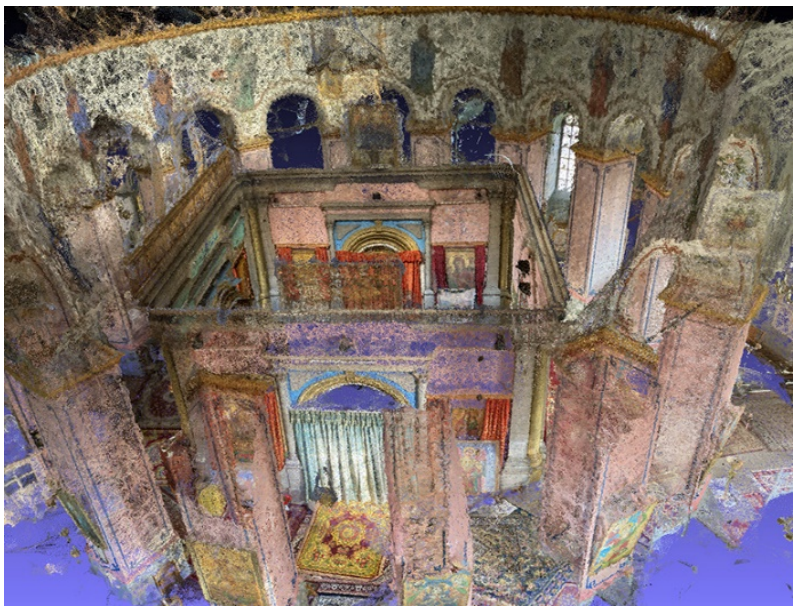

Figure 12: Decimated point cloud of the church.

These were then connected together in the FARO SCENE software. There, the initial processing, cleaning, filtering, colour correction, and stitching was carried out by https://www.scanthecity.com The unified point cloud was further migrated to additional software, including Cloud Compare, Reality Capture, Meshlab, etc. for further processing, cloud decimation and format conversion. In both cases the final models were immense (20-45 million points) and drastic decimation was needed in order to achieve a reasonable degree of fluid interactivity in the VR headset.

The interactive experience itself was developed in conventional gaming software. Early tests were carried out in Unity, but ultimately it was decided to move to the Unreal Engine development environment, as it proved more efficient in handling the point clouds. Finding the optimal balance between the best cloud density and usability was not easy, and at the time of writing tests are still ongoing.

\section{ISSUES}

\subsection{Private/public}

One of the inbuilt conflicts of the religious spiritual experience lies in the fact that it is intrinsically and profoundly personal, yet at the same time a communal, shared experience. Attending a Church, Synagogue or mosque is a social event and the emotional impact is elevated by the togetherness, singing, holding hands or even communal silence. The intense emotional impact of the crowd is no less apparent in football matches or in the joint singing of William Blake's Jerusalem at the last night of the Proms.

In parallel however, the spiritual experience is highly personal and inward looking. Me and my maker. Solitude, silence, an internal private journey. This is relevant to the VR experience, which by its very definition is and must be personal. The technology locks out the external world and all it contains. This can be both good and bad. It heightens the personal impact, yet at the same time it prevents the communal sharing experience.

\subsection{Application in context}

This issue raises the question of how, where and when the VR experience can or should be applied. The obvious answer would be in the user's private domain, when the muse is upon one and when the condition calls for it. However, in practice, very few people today have immediate access to high-end VR viewers such as the Oculus rift. This may well change in the not distant future as the technology becomes less cumbersome and more user friendly.

Another possible answer would be installation in public places such as churches. Sometimes these magnificent edifices would appear to be in danger of losing some of their spirituality, as they become tourist attractions. VR installations on site could possibly become virtual cloisters of seclusion and introspection.

\section{CONCLUSION}

Virtual reality is fast becoming the new reality. The digital explosion is expanding at an ever-growing pace and the technological experimentation described here will no doubt seem like child's play to the readers of this paper in the years to come. Therefore, the importance of the work must lie in the intrinsic questions raised regarding the role of technology in our spiritual lives and the application of 'gaming' software for other purposes.

Irrespective of the level of success that this particular project achieves, in its attempt to evoke an emotional sense of pilgrimage, it is the very attempt that must be regarded as relevant. For technology is part of our lives and will continue to evolve. Likewise, human nature will always crave a sense of purpose and belief. It is the motivation to unify and consolidate these two forces that lies at the core of this work, and this, it would seem, is to remain a never-ending task.

\section{TECHNOLOGIES UTILISED}

The following software was used for this project: Agisoft Metashape, Zephyr 3D Aerial, Reality Capture, Meshlab, CloudCompare, Autodesk MeshMixer, Unity 3D, Unreal Engine, Adobe Photoshop, Adobe Lightroom, Adobe Audition. The hardware used for this project consisted of the following: Nikon 5300 DSLR, Faro Focus S150 3D Laser Scanner, iPhone 11, Insta 360 camera. 


\section{REFERENCES}

Ben-Nathan, G. (2012) The Ethiopian Church in Jerusalem - Debre Genet (Sanctuary of Paradise) [online]. $\quad$ https://angloethiopian.org/publications/articles.php?type=A\&refe rence $=$ publications/articles/2012winter/jerusalem.p hp (retrieved 21 March 2020).

Cassuto, D. (2012) Synagogues in Italy until the 18th century. In: R. Weinstein (ed.) Israeli communities in the East during the nineteenth and twentieth centuries [Hebrew], Yad Ben Zvi. pp.169171.

Contessa, A. (2014) From Italy to Jerusalem. The birth of the Umberto Nahon Museum of Italian Jewish Art. In: R. Bonfil (ed.) The Italian Jewish Cultural Centre in the Heart of Jerusalem, Jerusalem.
Fabri, F. (1848) Fratris Felicis Fabri Evagatorium in Terrae sanctae, Arabiae in Aegypti peregrinationem, vol.3.

Isaacs, A. (2005) Modernity Comes to Jerusalem [online].

http://archive.jewishagency.org/jerusalem/content/2 3682 (retrieved 21 March 2020)

Twite, R. (2020) Africa in Jerusalem - The Ethiopian Church [online]. https://mfa.gov.il/MFA/MFA-

Archive/2003/Pages/Africa in Jerusalem - The Ethiopian Church.aspx (retrieved 21 March 2020). 